\title{
Penegakan Hukum dan Kedaulatan pada Wilayah Perbatasan Negara oleh Tentara Nasional Indonesia di Provinsi Sulawesi Utara
}

\author{
Hilmi Ardani Nasution ${ }^{1}$ \\ ${ }^{1}$ Badan Penelitian dan Pengembangan Hukum dan Hak Asasi Manusia \\ Corresponding author. Email: hilmikumham@gmail.com
}

Naskah diterima: 15-10-2020; revisi: 07-12-2020; disetujui: 17-12-2020

DOI: https://doi.org/10.46257/jrh.v24i2.133

\begin{abstract}
Abstrak
Sulawesi Utara sebagai salah satu wilayah Republik Indonesia memiliki kawasan laut yang luas dan berbatasan langsung dengan negara-negara tetangga. Potensi alam besar yang bersumber dari laut Sulawesi Utara berpotensi memberikan pemasukan negara yang sangat besar, selain itu juga berpotensi menimbulkan kerugian yang tidak kalah besarnya bagi negara jika penegakan hukum dan kedaulatan tidak dikedepankan. Salah satu peran penegakan hukum dan kedaulatan di wilayah perbatasan laut dilaksanakan oleh Tentara Nasional Indonesia (TNI), dibebankan tugas yang berat untuk menjaga kewibawaan negara dengan cara penerapan hukum yang sesuai dengan peraturan perundang-undangan yang belaku nasional maupun internasional. Berdasarkan latar belakang tersebut, rumusan masalah yang akan dijawab dalam tulisan ini adalah bagaimana penegakan hukum dan kedaulatan di kawasan perbatasan negara di Provinsi Sulawesi Utara oleh TNI. Tujuan penelitian ini adalah untuk menjabarkan tentang peran penegakan hukum dan kedaulatan oleh TNI dan memberikan gambaran kondisi nyata di kawasan perbatasan. Penelitian ini diharapkan dapat dijadikan sebagai bahan pertimbangan pemerintah dalam mengambil kebijakan terkait dengan kawasan perbatasan negara. Metode penelitian yang digunakan adalah kualitatif dengan bentuk penelitian hukum normatif dan empiris. Hasil penelitian bahwa Tentara Nasional Indonesia melaksanakan penegakan hukum dan kedaulatan sesuai dengan peraturan perundang-undangan yang berlaku, dilaksanakan dengan berkoordinasi dengan instansi terkait penegakan hukum. Permasalahan yang dihadapi di kawasan perbatasan Sulawesi Utara adalah antara lain pencurian ikan dan penyelundupan, terdapat juga permasalahan hukum terkait dengan kewarganegaraan di wilayah pulau Sulawesi Utara yang menimbulkan kebingungan dalam penegakan hukum oleh Tentara Nasional Indonesia. Kesimpulan bahwa TNI dalam hal ini Angkatan Laut (AL) memiliki tugas untuk melakukan penegakan hukum di laut sebagai bentuk dari penegakan kedaulatan Republik Indonesia di laut, namun penegakan hukum oleh TNI AL tidak termasuk dalam hal melaksanakan fungsi peradilan.
\end{abstract}

Kata kunci: Tentara Nasional Indonesia, penegakan hukum, kedaulatan Negara, Sulawesi Utara. 


\title{
Law Enforcement and Sovereignty in State Border Areas by the Indonesian National Army in North Sulawesi Province
}

\begin{abstract}
North Sulawesi as one of the territories of the Republic of Indonesia has a vast sea area and is directly adjacent to neighboring countries. The large natural potential that comes from the sea of North Sulawesi has the potential to provide a very large state income, besides that it also has the potential to cause no less great loss to the state if law enforcement and sovereignty are not prioritized. One of the roles of law enforcement and sovereignty in the maritime border area is carried out by the TNI, which is charged with the heavy duty of maintaining the authority of the state by implementing laws in accordance with national and international regulations. Based on this background, the formulation of the problem that will be answered in this paper is how the TNI is enforcing law and sovereignty in the border area of North Sulawesi Province. The purpose of this research is to describe the role of law enforcement and sovereignty by the TNI and provide a picture of the real conditions in the border area. This research is expected to be used as material for the government's consideration in making policies related to national border areas. The research method used is qualitative with the form of normative and empirical legal research. The conclusion that can be drawn from this paper is that the Indonesian National Army carries out law enforcement and sovereignty in accordance with the applicable laws and regulations, carried out in coordination with relevant law enforcement agencies. Problems faced in the border area of North Sulawesi are, among others, illegal fishing and smuggling. There are also legal issues related to citizenship in the island of North Sulawesi which have caused confusion in law enforcement by the Indonesian National Army.
\end{abstract}

Keywords: The National Army of Indonesia, law enforcement, State sovereignty, North Sulawesi.

\section{Pendahuluan}

Provinsi Sulawesi Utara merupakan salah satu di wilayah Republik Indonesia yang menjadi garda terdepan kawasan perbatasan. Status garda terdepan tercermin dari lokasi Sulawesi Utara yang memiliki perbatasan laut yang luas yang berbatasan langsung dengan beberapa negara tetangga. Kawasan laut yang luas di bagian utara Indonesia ini menimbulkan potensi-potensi pelanggaran hukum yang bersifat nasional maupun transnasional. Wilayah perbatasan di Sulawesi Utara dengan begitu menjadi salah satu ujian penegakan hukum di Indonesia terkait dengan kawasan perbatasan negara. Penegakan 
hukum di kawasan perbatasan menjadi wajah penegakan hukum Indonesia di mata dunia internasional.

Fungsi dan peranan wilayah perbatasan tidak saja sebagai tanda bahwa wilayah sebuah negara mencakup wilayah geografis tertentu dan wilayah perbatasan itu tidak dapat dilanggar oleh negara tetangga. Manifestasi nyata dari wilayah perbatasan juga berhubungan dengan kedaulatan penuh sebuah negara (Indonesia), yang mesti dihormati oleh negara-negara tetangga, tetapi juga oleh warga negara (Indonesia) sendiri. Kedaulatan (sovereignty) sering hanya dikaitkan secara fisik (bahwa wilayah Indonesia) tidak diambil oleh negara lain, kokohnya pengaruh negara (state government) disetiap wilayah negara, patuhnya warga negara terhadap ketentuan-ketentuan negara, dan sejumlah ketentuan lain yang mendukung kedaulatan itu terus terwujud. Konsepsi sempit tentang kedaulatan (secara politik) yang diperkenalkan oleh pemerintah pusat dan pemerintah daerah menjadi tantangan tersendiri saat ini dalam era globalisasi, dimana melintasi batas (manusia dan barang) bukan lagi sebuah isu baru. Kedaulatan sebab kesamaan ideologi dan perasaan berbangsa, bernegara, dan bermasyarakat tidak lagi menjadi "ideal types" dalam mempertahankan keutuhan sebuah negara. Kedaulatan dalam dimensi luas termasuk, bagaimana warga negara merasa dan mengalami bahwa mereka diperhatikan, dimakmurkan dan dijamin oleh negaranya. Ungkapan klasik selama ini bahwa "wilayah perbatasan adalah beranda depan negara" mulai kusut maknanya, sebab warga merasa ungkapan itu hanya sekedar permainan ideologi dan kebijakan untuk menjaga lunturnya perasaan sebagai warga negara Republik Indonesia.

Secara umum terdapat banyak ujian kewibawaan negara terjadi di wilayah perbatasan, mulai dari wilayah perbatasan darat, laut, udara, meliputi permasalahan ekonomi, infrastruktur, pendidikan, kedaulatan negara, dan hukum. Secara geografis wilayah negara Indonesia berada di atas daratan dan laut wilayah yang terbentang garis $95^{\circ} \mathrm{BT}$ dan $141^{\circ} \mathrm{BT}$ serta mulai dari $6^{\circ} \mathrm{LU}$ sampai $11^{\circ}$ LS, dengan batas-batas yang telah diatur dalam peraturan perundang-undangan. Dengan batas tersebut ruang udara Indonesia tergambar sebagai dimensi ruang yang sangat luas (5.193.252 kilometer persegi), dimana 
sekaligus menggambarkan besarnya peluang untuk menjaganya dan mendapatkan keuntungan ekonomi. Pada umumnya batas wilayah udara suatu negara terletak di batas terluar dari laut wilayahnya dan dengan demikian mencakup udara di atas wilayah darat, perairan pedalaman, perairan nusantara, dan laut wilayah. Dengan demikian maka batas-batas wilayah udara Indonesia juga masih bersifat kira-kira. Persoalan di kawasan perbatasan Indonesia, belum lagi termasuk di perairan/laut Indonesia yang berbatasan dengan Malaysia, Filipina, Kepulauan Palau, Timor Leste, Australia, Papua Nugini, dan Vietnam yang menjadi ajang pencurian ikan oleh awak kapal negara asing.

Kementerian Keuangan mengungkapkan bahwa di tahun 2017 penyelundupan narkotika melalui perbatasan meningkat, terutama di wilayah perbatasan Indonesia-Malaysia. Januari 2018, Polisi Entikong menggagalkan penyelundupan 17 calon Tenaga Kerja Indonesia (TKI) ilegal yang akan diselundupkan melalui jalur tidak resmi, lalu Satgas perbatasan Indonesia-Timor Leste yang TNI tergabungnya di dalamnya berhasil menggagalkan penyelundupan ratusan liter BBM ilegal. Lebih mengejutkan lagi pada pertengahan 2017 diketahui terdapat lapangan golf milik pengusaha Malaysia di batas teritorial RI-Malaysia tepatnya di patok F210 Desa Pala Pasang, Kecamatan Entikong. Dari gambaran kecil kasus tersebut, masih beragam jenis kejahatan transnasional seperti illegal logging, illegal fishing, human trafficking, penjualan minyak secara ilegal di laut, dan ragam kejahatan ditambah pelanggaran-pelanggaran perbatasan yang mengganggu kedaulatan Indonesia di wilayah perbatasan. Potensi kerugian negara akibat penangkapan ikan ilegal di Sulawesi Utara bisa bernilai hingga 100 triliun per tahun(M. Razi Rahman, 2019). Kementerian Perikanan pada tahun 2018 bahkan mengakui bahwa Indonesia pernah mengalami kerugian hingga mencapai angka 2.000 Triliun.(CNBC Indonesia, 2018)

Gambaran yang sering ditampilkan di wilayah perbatasan adalah akibat dari masalah penegakan hukum dan kedaulatan negara, mengingat wilayah perbatasan merupakan wilayah yang rawan akan kejahatan yang bersifat transnasional. Penegakan hukum di wilayah perbatasan merupakan bukti dari 
adanya kontrol dari negara terhadap wilayahnya, dan penegakan hukum dilaksanakan oleh organ-organ pemerintah seperti kepolisian, kejaksaan, imigrasi, dan organ litigasi pengadilan. Koordinasi antar penegak hukum menjadi sorotan ketika didapati pelanggaran lintas batas yang tidak terpantau oleh aparat penegak hukum. Di bidang pertahanan dan keamanan, TNI memiliki tugas pokok menegakkan kedaulatan negara, mempertahankan keutuhan wilayah Negara Kesatuan Republik Indonesia, serta melindungi Indonesia dari ancaman dan gangguan terhadap keutuhan bangsa dan negara. TNI hadir diperbatasan bukan tanpa kendala, disamping permasalahan kuantitas personel yang tidak mencukupi yang hanya 1 (satu) persen dari jumlah penduduk, juga ada kekurangan alat utama sistem persenjataan (Alutsista) yang tidak didukung persenjataan berat untuk pemantauan, logistik, maupun tempur (radar, pesawat angkut, pesawat pembom, panser, tank, artileri dan sebagainya) tidak jauh dari akibat kekurangan penganggaran. Kekurangan yang menjadi masalah lain adalah industri pendukung TNI yang belum berkembang menciptakan ketidakmandirian alutsista Indonesia, sehingga kebutuhan perlengkapan TNI sangat bergantung pada produk luar negeri.(Suharyo, 2016: 84-85)

Peranan TNI dalam penegakan kedaulatan negara, yaitu secara meluas melalui Undang-Undang Nomor 34 Tahun 2004 tentang TNI. Kewenangan bahkan tanggung jawab TNI dalam penegakan kedaulatan negara, juga harus melaksanakan berbagai peraturan perundang-undangan lainnya seperti UndangUndang Nomor 43 Tahun 2008 tentang wilayah negara, Undang-Undang Nomor 6 Tahun 1996 tentang Perairan, Undang-Undang Nomor 1 Tahun 2009 tentang Penerbangan, dan lainnya. Disamping itu juga dilengkapi dengan peraturan pemerintah seperti PP Nomor 36 tahun 2002 tentang Hak dan Kewajiban Kapal, PP Nomor 37 Tahun 2002 tentang Hak dan Kewajiban Kapal dan Pesawat Asing, serta PP Nomor 4 Tahun 2018 tentang Pengamanan Wilayah Udara.

Sulawesi Utara yang memiliki kawasan perbatasan yang berupa perairan memiliki permasalahan tersendiri. Berbeda dengan provinsi yang memiliki kawasan perbatasan berupa daratan, kawasan perbatasan laut mempunyai kesulitan terkait dengan patok perbatasan. Perbatasan darat dapat secara nyata 
dibuat dan dilihat, sedangkan perbatasan laut sulit untuk menentukan batas-batas nyata seperti patok apda perbatasan darat. Kesulitan tersebut menjadi tantangan tersendiri bagi penegak hukum di kawasan perbatasan Sulawesi Utara. (Lusy Gerungan, 2016: 11) Dalam hal penegakan hukum dan kedaulatan di wilayah perbatasan negara, Provinsi Sulawesi Utara terdapat beberapa instansi penegak hukum yang berperan, tulisan ini akan menitik beratkan kepada penegakan hukum yang dilaksanakan oleh TNI. TNI AL banyak diasumsikan oleh publik sebagai komponen dalam keamanan negara yang hanya memiliki tugas yang berkaitan dengan peperangan dan konflik, namun ternyata dalam rangkaian peraturan perundang-undangan TNI AL memiliki peran penegakan hukum juga. Tren pengamanan kawasan perbatasan di negara-negara lain juga semakin mengedepankan peran militer dengan penerapan teknologi yang lebih baru untuk meningkatkan keamanan hingga mencapai pengawasan maksimal dan kontrol yang efektif di kawasan perbatasan.(Jones \& Johnson, 2016: 8)

Tulisan ini mencoba menjelaskan peran TNI tersebut. TNI berdasarkan Pasal 4 Undang-Undang Nomor 34 Tahun 2004 tentang Tentara Nasional Indonesia terdiri atas TNI Angkatan Darat, TNI Angkatan Laut, dan TNI Angkatan Udara. Sulawesi Utara yang memiliki wilayah laut yang luas dan memilki sumber alam laut yang besar, maka dalam dalam hal ini Angkatan Laut (TNI AL) memiliki peran yang besar dalam di wilayah laut perbatasan negara. TNI AL dalam Pasal 9 Undang-Undang Nomor 34 Tahun 2004 juga diberikan peranan penegakan hukum dan menjaga keamanan di wilayah laut. Berdasarkan latar belakang tersebut, maka dalam makalah ini akan mebahas mengenai:

a. Peranan TNI dalam penegakan hukum dan kedaulatan di kawasan perbatasan;

b. Peran TNI AL di perbatasan Sulawesi Utara yang memiliki wilayah laut luas yang memiliki perbatasan negara yang luas pula?

Kebaruan dalam penelitian ini adalah mencoba menggali peran TNI secara nyata di lapangan, yaitu di Sulawesi Utara. Masih minim kajian dan penelitian yang membahas mengenai peran langsung TNI dalam penegakan hukum dan kedaulatan negara di Sulawesi Utara. Telah terdapat banyak kajian yang 
membahas peran TNI secara normatif, namun peran TNI secara spesifik di wilayah kawasan perbatasan Sulawesi Utara masih belum banyak. Oleh karena itu, tulisan ini mencoba berkontribusi dalam memperkaya khazanah keilmuan mengenai perbatasan wilayah negara dengan mengedepankan contoh di Sulawesi Utara.

Spesifikasi tulisan ini adalah penggabungan antara penelitian hukum normatif dan penelitian hukum empiris. Penelitian hukum normatif mencakup penelitian terhadap asas-asas dan terori-teori hukum, sistematika hukum, taraf sinkronisasi vertikal dan horizontal, perbandingan hukum dan sejarah hukum. Data yang diperoleh berasal dari bahan pustaka berupa literatur terpilih, peraturan perundang-undangan terkait, berita daring, dan lain-lain yang terkait dengan judul yang kemudian dianalisis dan didiskusikan dengan para pihak untuk menentukan jawaban terhadap penelitian ini. Untuk itu penelitian ini lebih menitikberatkan pada penelitian kepustakaan (library research). Sedangkan pada penelitian hukum empiris dilakukan melalui penelitian lapangan melalui wawancara mendalam (in-depth interview) dengan informan terkait dalam penegakan hukum dan kedaulatan negara yaitu TNI.(Soerjono Soekanto \& Mamudji, 1990: 11)

\section{Pembahasan}

\section{A. Penegakan Hukum dan Kedaulatan oleh TNI di Kawasan Perbatasan}

Penegakan hukum adalah kegiatan menyerasikan hubungan nilai-nilai yang terjabarkan di dalam kaidah-kaidah atau pandangan nilai yang mantap dan mengejewantah dan sikap tindak sebagai rangkaian penjabaran nilai tahap akhir untuk menciptakan, memelihara dan mempertahankan kedamaian pergaulan hidup. Penjabaran mengenai penegakan hukum lebih diperinci oleh Soerjono Soekanto dalam beberapa faktor yang harus difungsikan dengan benar-benar yaitu pemberian teladan kepatuhan hukum oleh para penegak hukum, sikap yang lugas dari para penegak hukum, penyesuaian peraturan yang berlaku dengan perkembangan teknologi mutakhir, penerangan dan penyuluhan mengenai peraturan yang berlaku terhadap masyarakat, dan memberi waktu yang cukup 
bagi masyarakat untuk memahami peraturan yang dibuat. Berdasarkan hal tersebut, bisa disimpulkan bahwa penegakan hukum dapat berjalan dipengaruhi oleh faktor-faktor (Soerjono Soekanto, 2007: 2) sebagai berikut: .

1) Faktor hukumnya sendiri

2) Faktor penegak hukum (pembentuk maupun penerap hukum)

3) Faktor sarana atau fasilitas yang mendukung penegakan hukum

4) Faktor masyarakat, yakni masyarakat di mana hukum tersebut diterapkan

5) Faktor kebudayaan, yakni sebagai hasil karya, cipta dan karsa yang didasarkan pada karsa manusia di dalam pergaulan hidup

Jika masih terjadi pelanggaran-pelanggaran terhadap hukum, berarti masih ada faktor-faktor yang belum terpenuhi dalam penegakan hukum di wilayah perbatasan. Penjelasan Soerjono Soekanto tentang penegakan hukum menjadi indikator tersendiri untuk membantu dalam melaksanakan penelitian, menemukan dalam aspek penegakan hukum.

Kedaulatan negara merupakan hal yang paling fundamental dalam hukum internasional, kedaulatan adalah hal yang melekat pada setiap negara yang merdeka. Kedaulatan diartikan sebagai otoritas tertinggi, mutlak, dan tidak dapat dikendalikan yang dimiliki oleh sebuah negara merdeka di bawah pemerintah dengan otoritas politik tertinggi, mempunyai hak dan kekuatan untuk mengatur urusan dalam negeri tanpa intervensi dari negara lain. (Munir Fuady, 2003: 46) Penjelasan ini menerangkan kedaulatan sebuah negara wujudnya adalah mengatur dan mengelola, demikian kuatnya definisi kedaulatan sampai diartikan sama sekali tidak bisa diganggu gugat, menunjukkan bahwa kehormatan negara terletak pada kedaulatannya. Namun dalam perkembangannya, kedaulatan bukan berarti negara bisa berbuat apa saja, ada norma lain yang membuat kedaulatan itu ada batasnya.

Dalam hal kedaulatan, Piagam PBB tidak membeda-bedakan kedaulatan satu negara dengan negara lain, tercantum pada Pasal 2 ayat (1) bahwa PBB adalah organisasi yang menerapkan prinsip kesamaan kedaulatan kepada semua negara anggota. Oleh karena itu setiap negara memiliki kedudukan yang sama dalam pengelolaan wilayah perbatasan, Indonesia dengan negara tetangga tidak 
ada pembedaan dan seharusnya setiap kerjasama yang dijalankan dengan negara tetangga dapat mendatangkan keuntungan bagi setiap negara.

Mengenai batas kedaulatan yang lebih berimbang, Mochtar Kusumaatmadja menjelaskan kedaulatan dalam arti yang wajar, satu sisi memang sebagai kekuasaan tertinggi sebuah negara, namun pada sisi lain terbatas di wilayah negara itu, artinya suatu negara hanya memiliki kekuasaan tertinggi di dalam batas wilayahnya, dan secara logis terbatas dalam kedaulatan negara lain. Negara yang berdaulat adalah negara merdeka yang satu bebas dari yang lainnya, juga mempunyai derajat yang sama dengan lainnya. (Mochtar Kusumaatmadja, 2003: 16-19)

Kedaulatan Indonesia terbatas sebatas Wilayah Negara Kesatuan Republik Indonesia, yang selanjutnya disebut dengan Wilayah Negara. Wilayah negara berdasarkan Pasal 1 Undang-Undang Nomor 43 Tahun 2008 tentang Wilayah Negara adalah salah satu unsur negara yang merupakan satu kesatuan wilayah daratan, perairan pedalaman, perairan kepulauan dan laut teritorial beserta dasar laut dan tanah di bawahnya, serta ruang udara di atasnya, termasuk seluruh sumber kekayaan yang terkandung di dalamnya. Kawasan pertemuan Indonesia dengan negara tetangga disebut sebagai Kawasan Perbatasan adalah bagian dari Wilayah Negara yang terletak pada sisi dalam sepanjang batas wilayah Indonesia dengan negara lain, dalam hal Batas Wilayah Negara di darat, Kawasan Perbatasan berada di kecamatan.

Peran TNI dalam penegakan hukum dan kedaulatan negara tentunya berdasarkan pada kerangka peraturan perundang-undangan yang berkaitan dengan tugas dan fungsi TNI. Peraturan yang mengatur peran TNI dalam penegakan hukum dan kedaulatan adalah sebagai berikut:

Tabel 1. Kerangka Regulasi

terkait Fungsi Penegakan Hukum dan Kedaulatan Negara oleh TNI

\begin{tabular}{|l|l|}
\hline \multicolumn{1}{|c|}{ Regulasi } & Peranan TNI Penegakan Hukum dan Kedaulatan Negara \\
\hline UU No. 34 Tahun 2004 & $\begin{array}{l}\text { Pasal 7, Ayat 1 } \\
\text { tentang Tentara Nasional } \\
\text { Indonesia }\end{array}$ \\
& $\begin{array}{l}\text { Tugas pokok TNI adalah menegakkan kedaulatan negara, } \\
\text { yang berdasarkan Pancasila dan Undang-Undang Dasar Negara Republik } \\
\text { Indonesia Tahun 1945, serta melindungi segenap bangsa dan seluruh } \\
\text { tumpah darah Indonesia dari ancaman dan gangguan terhadap keutuhan } \\
\text { bangsa dan negara. }\end{array}$ \\
\hline
\end{tabular}




\begin{tabular}{|c|c|}
\hline & $\begin{array}{l}\text { Pasal 9, poin (b) } \\
\text { menegakkan hukum dan menjaga keamanan di wilayah laut yurisdiksi } \\
\text { nasional sesuai dengan ketentuan hukum nasional dan hukum internasional } \\
\text { yang telah diratifikasi; } \\
\text { Pasal 10, poin (b) } \\
\text { menegakkan hukum dan menjaga keamanan di wilayah udara yurisdiksi } \\
\text { nasional sesuai dengan ketentuan hukum nasional dan hukum internasional } \\
\text { yang telah diratifikasi; }\end{array}$ \\
\hline $\begin{array}{l}\text { UU No. } 32 \text { Tahun } 2014 \\
\text { Tentang Kelautan }\end{array}$ & $\begin{array}{l}\text { Pasal 58, Ayat } 2 \\
\text { Sistem pertahanan laut sebagaimana dimaksud pada ayat (1) } \\
\text { diselenggarakan oleh kementerian yang menyelenggarakan urusan } \\
\text { pemerintahan di bidang pertahanan dan Tentara Nasional Indonesia. }\end{array}$ \\
\hline $\begin{array}{l}\text { UU No. } 3 \text { Tahun } 2002 \\
\text { tentang Pertahanan } \\
\text { Negara } \\
\text { Pasal } 10\end{array}$ & $\begin{array}{l}\text { Pasal 10, Ayat } 3 \\
\text { Tentara Nasional Indonesia bertugas melaksanakan kebijakan pertahanan } \\
\text { negara untuk: } \\
\text { a. mempertahankan kedaulatan negara dan keutuhan wilayah; } \\
\text { b. melindungi kehormatan dan keselamatan bangsa; } \\
\text { c. melaksanakan Operasi Militer Selain Perang (OMSP); dan } \\
\text { d. ikut serta secara aktif dalam tugas pemeliharaan perdamaian regional } \\
\text { dan internasional. }\end{array}$ \\
\hline $\begin{array}{l}\text { UU No. } 6 \text { Tahun } 1996 \\
\text { tentang Perairan } \\
\text { Indonesia }\end{array}$ & $\begin{array}{l}\text { Pasal 24, Ayat } 3 \text { dan penjelasannya } \\
\text { Apabila diperlukan, untuk pelaksanaan penegakan hukum sebagaimana } \\
\text { dimaksud dalam ayat (1) dan ayat (2) dapat dibentuk suatu badan } \\
\text { koordinasi yang ditetapkan dengan Keputusan Presiden. } \\
\text { Penjelasan: Penegakan hukum dilaksanakan oleh instansi terkait, antara } \\
\text { lain Tentara Nasional Indonesia Angkatan Laut, Kepolisian Negara } \\
\text { Republik Indonesia, Departemen Perhubungan, Departemen Pertanian, } \\
\text { Departemen Keuangan, dan Departemen Kehakiman, sesuai dengann } \\
\text { wewenang masing-masing instansi tersebut dan berdasarkan ketentuan } \\
\text { peraturan perundang-undangan nasional maupun hukum intenasional. }\end{array}$ \\
\hline $\begin{array}{l}\text { UU No. } 3 \text { Tahun } 2002 \\
\text { tentang Pertahanan } \\
\text { Negara }\end{array}$ & $\begin{array}{l}\text { Pasal 10, Ayat } 3 \\
\text { Tentara Nasional Indonesia bertugas melaksanakan kebijakan pertahanan } \\
\text { negara untuk: } \\
\text { a. mempertahankan kedaulatan negara dan keutuhan wilayah; } \\
\text { b. melindungi kehormatan dan keselamatan bangsa; } \\
\text { c. melaksanakan Operasi Militer Selain Perang; dan } \\
\text { d. ikut serta secara aktif dalam tugas pemeliharaan perdamaian regional } \\
\quad \text { dan internasional. }\end{array}$ \\
\hline $\begin{array}{l}\text { PP No. } 4 \text { Tahun } 2018 \\
\text { tentang Pengamanan } \\
\text { Wilayah Udara Republik } \\
\text { Indonesia }\end{array}$ & $\begin{array}{l}\text { Pasal 1, Ayat 17 } \\
\text { Pesawat Udara Tentara Nasional Indonesia yang selanjutnya disebut } \\
\text { Pesawat Udara TNI adalah pesawat udara yang dipergunakan oleh Tentara } \\
\text { Nasional Indonesia yang diberi kewenangan untuk menegakkan hukum } \\
\text { dan pengamanan Wilayah Udara sesuai dengan ketentuan peraturan } \\
\text { perundangundangan. }\end{array}$ \\
\hline $\begin{array}{l}\text { PP No. } 36 \text { tahun } 2002 \\
\text { tentang Hak dan } \\
\text { Kewajiban Kapal, PP } \\
\text { Nomor } 37 \text { Tahun } 2002 \\
\text { tentang Hak dan } \\
\text { Kewajiban Kapal dan } \\
\text { Pesawat Asing }\end{array}$ & $\begin{array}{l}\text { Sebagai turunan dari Undang-Undang Nomor } 6 \text { Tahun } 1996 \text { tentang } \\
\text { Perairan yang memberi kewenangan penegakan hukum kepada salah } \\
\text { satunya TNI AL }\end{array}$ \\
\hline
\end{tabular}

TNI terbagi dari tiga bagian utama tergantung matra masing-masing, darat, udara, dan laut. Penugasan jajaran TNI AD dalam penegakan kedaulatan negara 
di wilayah perbatasan darat antara Indonesia dengan negara tetangga, adalah melalui Pengamanan Perbatasan Batalyon Infanteri TNI AD, dengan mendirikan Pos Pengamanan serta mengadakan patroli di sepanjang perbatasan darat. Disamping itu, juga didukung oleh Kesatuan Teritorial Koramil, Kodim, Korem serta Kodam. Khusus untuk penegakan kedaulatan negara yang berbatasan dengan laut (maritim) dengan negara tetangga, dilakukan oleh TNI AL melalui Komando Armada I, II, dan III, dengan melakukan patroli kapal perang TNI AL berikut dengan berbagai unsur pendukungnya. Untuk menegakkan kedaulatan negara di pulau-pulau terluar atau terdepan telah ditempatkan kesatuan marinir dengan kekuatan tertentu. TNI AL juga ditugasi untuk mengamankan Alur Laut Kepulauan Indonesia (ALKI) melalui Peraturan Pemerintah Nomor 36 Tahun 2002 tentang Hak dan Kewajiban Kapal Asing dalam Melaksanakan Lintas Damai Melalui Perairan Indonesia, dan Peraturan Pemerintah Nomor 37 Tahun 2002 tentang Hak dan Kewajiban Kapal dan Pesawat Udara Asing dalam Melaksanakan Hak Lintas Alur Laut Kepulauan Melalui Alur Laut Kepulauan yang ditetapkan. (Suharyo, 2016: 99-101)

Secara khusus TNI AL menegakkan hukum dan menjaga keamanan adalah segala bentuk kegiatan yang berhubungan dengan penegakan hukum di laut sesuai dengan kewenangan TNI AL (constabulary function) yang berlaku secara universal dan sesuai dengan ketentuan perundang-undangan yang berlaku untuk mengatasi ancaman tindakan, kekerasan, ancaman navigasi, serta pelanggaran hukum di wilayah laut yurisdiksi nasional. Penegakan hukum yang dilaksanakan oleh TNI AL di laut, terbatas dalam lingkup pengejaran, penangkapan, penyelidikan, dan penyidikan perkara yang selanjutnya diserahkan kepada kejaksaan, TNI AL tidak menyelenggarakan pengadilan. Sebagai contohnya TNI AL berkewenangan dalam kasus pencurian ikan di wilayah laut zona ekonomi ekslusif (ZEE) yaitu diwilayah 12 mil laut dari garis pangkal laut. TNI AL adalah penegak hukum dalam melaksanakan penangkapan dan penyidikanya. Berbeda jika pencurian ikan terjadi di laut pantai, maka Penyidik Pegawai Negeri Sipil Dinas Kelautan dan Perikanan adalah yang berkewenangan di wilayah laut pantai, dan PPNS Dinas Kelautan dan Perikanan 
adalah yang berkewenangan dalam melaksanakan penyidikan. (Wasrizal, 2020: 214) Batasan-batasan tersebut mengingat penegakan hukum di wilayah laut melibatkankan banyak unsur dari pemerintahan.

Kewenangan TNI AL dalam penegakan hukum menempatkan TNI AL sebagai satu-satunya kekuatan militer yang diberi mandat untuk melakukan penegakan kedaulatan dan hukum serta menjaga keamanan wilayah laut. TNI AL dalam menegakkan hukum di laut tetap harus tunduk pada hukum internasional dan hukum nasional, serta protap penegakan hukum internal TNI AL. (Sudardi, 2014: 25) Penegakan hukum oleh TNI AL dalam pelaksanaannya membutuhkan tambahan dukungan sarana dan prasarana yang baik terutama pada wilayah perbatasan laut. Penyediaan sarana dan prasarana tersebut mengingat praktek strategi kejahatan yang terjadi di wilayah perbatasan laut yang mengalami perkembangan dengan dukungan perkembangan teknologi mutakhir yang dimanfaatkan oleh para pelaku kejahatan di wilayah perbatasan laut. Selain itu, pelaku bekerja dengan pengorganisasian yang teratur dan kegiatannya melintasi batas negara. Dengan begitu, penegakan hukum yang dilakukan TNI AL di wilayah perbatasan laut dapat dijalankan secara maksimal. (Grace H. Tampongangoy, 2016: 31)

Peran TNI AL dalam penegakan hukum di wilayah perbatasan laut sangat dibutuhkan, mengingat kawasan laut Indonesia yang sangat luas dan keterbatasan yang dimiliki oleh instansi penegak hukum di kawasan laut lainnya. Sebagai contoh, BAKAMLA yang memilki keterbatasan unit kapal untuk melakukan operasi sendiri, maka dari itu BAKAMLA rutin melaksanakan operasi terpadu yang juga melibatkan TNI AL dalam penegakan hukum di laut. Berdasarkan fakta ini, TNI AL perlu melakukan sinergi yang baik antara penegak hukum di wilayah laut Indonesia untuk memaksimalkan penegakan hukum dan kedaulatan. (Agus Haryanto Ikhsanudin, 2017: 61) Peranan Badan Keamanan Laut (Bakamla), secara khusus, adalah membangun dan mengoperasikan berbagai sarana dan prasarana pengawasan dan pengendalian sebagaimana yang dipersyaratkan oleh the International Maritime Organization (IMO). Sekaligus mempertahankan kedaulatan dan supervisi hukum di wilayah 
yurisdiksi perairan Indonesia. Berkenaan dengan hal tersebut, sinergisitas antara TNI AL dengan Bakamla, dan juga institusi penegakan hukum lainnya (semisal kejaksaan, kepolisian) jika terdapat tersangka pelaku kejahatan tertentu yang diamankan oleh TNI AL di Laut, koordinasi dengan pihak terkait telah dan terus dilakukan. Keteraturan dalam kawasan perbatasan laut membutuhkan langkah kolaboratif antar instansi terkait untuk menciptakan ekonomi di kawasan laut yang menghasilkan bagi negara. (Blaine \& Nel, 2019: 108)

\section{B. Peran TNI di Kawasan Perbatasan Sulawesi Utara}

Tugas utama Lantamal VIII antara lain mendukung operasi dari unsur TNI Angkatan Laut (AL) melalui pangkalan-pangkalan AL. Selanjutnya Operasi penegakan hukum dan keamanan laut, AL mempunyai tugas sendiri yang berbeda yaitu dalam hal penegakan hukum di laut, dan terakhir adalah pembinaan wilayah pertahanan laut dengan membina penduduk pesisir bagaimana mereka melakukan dukungan dalam pertahanan laut. Tugas tambahan dari Lantamal VIII adalah sebagai wakil ketua delegasi Indonesia dengan Filipina di pos perbatasan, melaksanakan pertemuan-pertemuan dengan Filipina terkait perbatasan, melakukan koordinasi dengan perwakilan Filipina (Konsulat Jenderal Filipina Sulawesi Utara).

Lantamal VIII membawahi beberapa Lanal, yaitu Lanal Melonguane, Lanal Tahuna, Lanal Toli-Toli dan Lanal Gorontalo. Setiap Lanal menjadi pangkalan untuk operasi AL yang meliputi peta wilayah laut Pulau Sulawesi yang sangat luas berbatasan langsung dengan Filipina. Dengan wilayah laut yang sangat luas mempunyai potensi kerawanan seperti illegal fishing, illegal entry dari Filipina, penyelundupan barang-barang dan kegiatan menonjol seperti penangkapan ikan menggunakan bahan peledak. Jangkauan sangat luas, sampai ke perbatasan Palau. Lanal membawahi POSAL (Pos Angkatan Laut), paling terdepan terdekat dengan perbatasan Filipina ada POSAL Marore, POSAL Miangas, dan POSAL Marampit.

Pada tahun 2017 Lantamal VIII menggelar operasi yaitu Operasi Perisai Ambalat 17, Operasi Kawanua 17, Operasi Trisila 17, Operasi Kilat Badik 17, 
Operasi Samudera Jaya 17, Operasi Komodo Jaya 17, dan Operasi Lolosi Jaya 17. Operasi didukung armada Lantamal VIII, radar, dan pesawat patroli udara. Kegiatan penegakan hukum pada tahun 2017 berhasil menangkap simpatisan ISIS dan setelah itu dikoordinasikan dengan Densus 88 terkait penanganan lebih lanjut.

Lebih lanjut hasil operasi Lantamal VIII selama 2017 adalah 8,4 Miliar denda yang masuk kas negara dari illegal fishing. Illegal fishing adalah diartikan sebagai kegiatan perikanan yang tidak sah, kegiatan perikanan yang tidak diatur oleh peraturan yang ada, atau aktivitasnya tidak dilaporkan kepada suatu institusi atau lembaga pengelola perikanan yang tersedia.(Nunung Mahmudah, 2015: 80) Selain itu penyelundupan miras juga marak di wilayah kerja Lantamal VIII, miras cap tikus diselundupkan ke wilayah timur lainnya karena harga jual di daerah timur seperti Papua lebih tinggi sebagai contoh di Manado harga miras sekitar Rp. 20.000, dijual ke Papua itu bisa menjadi Rp. 100.000. Penyelundupan hewan juga marak terjadi juga terkait harga jual yang mendatangkan keuntungan.

Di wilayah kerja Lantamal VIII yang paling menonjol selain illegal fishing dan penyelundupan adalah terkait illegal entry. illegal entry adalah orang yang melintasi batas-batas negara dengan tidak mematuhi persyaratan-persyaratan yang diperlukan untuk masuk secara sah ke dalam negara penerima. (Ricky H. Sampurna, 2019: 5) Fenomena iilegal entry di Sulawesi Utara dikenal di Sulawesi Utara dengan istilah SAPI-PISANG (Sangir Filipin-Filipin Sangir). Pelaku illegal entry ini mengalami permasalahan kewarganegaraan, di Indonesia menjadi masalah karena tidak diakui kewarganegaraannya begitu juga di Filipin menjadi masalah juga terkait permasalahan kewarganegaraannya. Permasalahan ini perlu menjadi perhatian pemerintah, karena mereka yang beramasalah dengan kewarganegaraannya membutuhkan penyelesaian agar mereka tidak mengalami kebingungan tanpa kepastian hukum. Mereka yang disebut SAPIPISANG ini sebenanrya menyimpan potensi yang bagus di bidang perikanan, mereka dikenal sebagai nelayan yang ahli, tenaga mereka bisa dimanfaatkan di lautan Indonesia. Namun karena secara kewarganegaraan mereka bermasalah, 
maka ini harus menjadi perhatian tersendiri, orang-orang SAPI-PISANG bisa dikatakan setengah Indonesia dan setengah Filipina, pemerintah perlu memberikan solusi kepada mereka yang bermasalah dengan kewarganegaraan. Penyelesaian permasalahan kewarganegaraan juga untuk menyelesaikan permasalahan terkait illegal entry di wilayah perbatasan dan memudahkan pihak pengamanan dalam melaksanakan tugasnya, karena fenomena tersebut membuat kebingungan dan dilema tersendiri dalam pelaksanaan penegakan hukum di kawasan perbatasan oleh TNI AL.

Mengenai pengelolaan hak-hak kewarganegaraan masyarakat di wilayah perbatasan menjadi tugas dari pemerintah daerah provinsi dan kota/kabupaten. Pemerintah daerah memiliki tugas memastikan terpenuhinya hak-hak dasar warga negara di wilayah perbatasan, dengan mengontrol dan mengelola sumber kekayaan yang ada untuk mendukung pengelolaan mulai dari sektor pendidikan, ekonomi, dan infrastruktur. Dengan adanya pengelolaan merupakan sebuah indikasi adanya penegakan kedaulatan negara di wilayah perbatasan.

TNI AL dalam melaksanakan tugas pengamanan wilayah laut tidak bisa bekerja sendiri, TNI AL juga memanfaatkan potensi maritim dan masyarakat maritim, TNI yang sangat terbatas sangat bergantung pada peran serta masyarakat dalam pengamanan wilayah laut dengan melaporkan penyelundupan atau ada orang asing masuk. TNI AL juga sampai ke pulau Miangas melakukan pengamanan, di Miangas jika melihat masyarakat itu sangat luar biasa dengan keadaan yang sangat terbatas. Dalam melaksanakan pengamanan AL melakukan koordinasi dengan unsur-unsur perbatasan yang lain.

TNI AL aktif dalam operasi penegakan hukum di wilayah laut, penempatan marinir di pulau-pulau terluar sudah efektif sejak tahun 2004. Mengenai aturan sesuai yang disampaikan, sudah ada diatur juga diatur Peraturan Pemerintah, pada prinsipnya Undang-Undang untuk melindungi dari orangnya, kapalnya, dan muatannya. Jadi semua dilakukan untuk perlindungan, teknis diatur di PP. Apakah relevansi PP itu sesuai kenyataan, setiap kasus berkembang dan berbeda, dan kadang hukum itu ada yang tidak bisa dijangkau, oleh karena itu pembaharuan peraturan teknis diperlukan, sebagai contoh trans national crime 
yang berkembang sudah mulai diatur yang dulu belum dibahas, dan juga extraordinary crime juga ke depan semakin berkembang tergantung kasus-kasus yang terjadi. Maka penelitian dan pengembangan peraturan teknis di wilayah perbatasan perlu diperbarui.

TNI AL di kawasan Sulawesi Utara juga melaksanakan patroli bersama dengan Angkatan Laut negara lain, yaitu sudah terjalin koordinasi patroli dengan Filipina. TNI AL patroli bersama, secara teknis TNI AL dan Angkatan Laut Filipina tetap berpatroli di wilayahnya masing-masing, tidak ada melintas ke wilayah negara lain. Patroli ini sifatnya koordinasi, jika ada permasalahan di perbatasan akan selesaikan bersama. (Nasution, 2016)

TNI AL di kawasan laut Provinsi Sulawesi Utara telah melakukan tugas dalam penegakan hukum dan kedaulatan negara dengan memanfaatkan sarana dan prasarana yang tersedia. TNI AL dalam pelaksanaan tugasnya menyadari bahwa fungsi penegakan hukum di kawasan laut bukan hanya dimiliki oleh TNI AL, terdapat instansi lain seperti Dinas Perikanan, BAKAMLA, Polair, dan dari Kementerian Perikanan. TNI AL telah melakukan koordinasi dengan instansi terkait dalam melaksanakan penegakan hukum, bahkan telah melakukan operasi bersama dengan angkatan laut negara tetangga. Secara teknis pelaksanaan tugas TNI AL di Sulawesi Utara telah maksimal menjalankan fungsi penegakan hukum dan kedaulatan sesuai denan peraturan perundang-undangan yang berlaku.

\section{Penutup}

\section{A. Kesimpulan}

Penegakan hukum dan kedaulatan di kawasan perbatasan Sulawesi Utara telah dilakukan oleh TNI AL berdasarkan pada Undang-Undang Nomor 34 Tahun 2004 tentang Tentara Nasional Indonesia. Disebutkan jelas dalam Pasal 9 bahwa tugas TNI AL adalah melakukan penegakan hukum di laut sebagai bentuk dari penegakan kedaulatan Republik Indonesia di laut, namun penegakan hukum oleh TNI AL tidak termasuk dalam hal melaksanakan fungsi peradilan. Penegakan hukum dan kedaulatan oleh TNI AL di kawasan perbatasan Sulawesi 
Utara dilakukan dengan melaksanakan berbagai operasi mandiri dan operasi gabungan yang melibatkan instansi-instansi terkait dalam penegakan hukum di kawasan laut. TNI AL di kawasan laut provinsi Sulawesi Utara menghadapi permasalahan maraknya illegal fishing, penyelundupan, dan illegal entry. Penegakan hukum terkait illegal fishing menjadi prioritas mengingat wilayah laut Sulawesi Utara yang begitu luas dan sumber daya alam yang melimpah menjadi sasaran utama bagi pelaku pencurian ikan yang berasal dari negara tetangga, dan berpotensi merugikan negara hingga milyaran setiap tahunnya. Selain itu illegal entry menjadi permasalahan tersendiri bagi TNI AL dalam melaksanakan penegakan hukum, mengingat hal tersebut adalah permasalahan kewarganegaraan yang perlu ditangani oleh aparat keimigrasian. Fenomena SAPI-PISANG yang ditemui TNI AL menimbulkan kebingungan dalam penegakan hukum, karena status kewarganegaraan pelaku yang dianggap setengah Indonesia dan setengah Filipina. Keterbatasan kapal patroli dan kapal perang TNI AL menjadi permasalahan penegakan hukum dan kedaulatan di Provinsi Sulawesi Utara, untuk meminimalisir permasalahan tersebut TNI AL memaksimalkan para nelayan di laut untuk menginformasikan keberadaan kapal-kapal asing yang melanggar ZEE Indonesia.

\section{B. Saran}

TNI AL sebagai salah satu stakeholder utama dalam penegakan hukum dan kedaulatan di wilayah perbatasan laut Provinsi Sulawesi Utara perlu memaksimalkan sinergi dengan instansi penegak hukum lain di Sulawesi Utara. Selain itu dibutuhkan dukungan sarana dan prasarana bagi TNI AL untuk mengamankan wilayah laut dengan penegakan hukum dan kedaulatan di Sulawesi Utara dengan, mengingat potensi pencurian sumber alam yang besar yang dapat menghasilkan kerugian negara yang besar. Pola koordinasi yang baik antar penegak hukum akan meningkatkan kualitas penegakan hukum dan kedaulatan di wilayah laut negara. Dibutuhkan payung hukum yang kuat untuk menjamin pelaksanaan penegakan hukum dan kedaulatan di wilayah laut negara, adalah payung hukum yang menjamin lancarnya sinergi atnar penegak hukum 
untuk menghindari permasalahan-permasalahan koordinasi yang menghambat progres penegakan hukum. Selain itu, negara perlu menyelesaikan permasalahan kewarganegaraan yang terjadi di Sulawesi Utara, mengingat peran TNI AL dalam hal tersebut adalah sangat terbatas dan membutuhkan dukungan instansi lain seperti keimigrasian dalam melaksanakan penegakan hukum terkait.

Menjaga kewibawaan negara di kawasan perbatasan wilayah negara adalah tugas seluruh komponen dalam sebuah negara. TNI tidak bisa bekerja sendirian karena fungsinya yang terbatas dalam beberapa hal, perlu sinergi dari instansi lain seperti pemerintah daerah, imigrasi, kepabeanan, karantina, dan tentunya masyarakat untuk mendukung pelaksanaan penegakan hukum dan kedaulatan di kawasan perbatasan negara. Oleh karena itu, pemerintah harus menjamin sinergi antar komponen negara berjalan baik dengan koordinasi yang baik.

\section{Daftar Pustaka}

Blaine, Mark, and Michelle Nel. "South African Maritime Foreign Policy: Rethinking the Role of The South African Navy." Scientia Militaria, South African Journal of Military Studies Vol. 47, No. 2, 2019.

Fuady, Munir. Aliran Hukum Kritis. Bandung: Citra Aditya Bakti, 2003.

Gerungan, Lusy KFR. "Penegakan Hukum Di Wilayah Perairan Indonesia." Jurnal Lex et Societas Vol. IV, No. 5, 2016.

Ikhsanudin, Agus Haryanto. "Sinergi BAKAMLA Dengan TNI AL Guna Penanggulangan Tindak Pidana Di Laut Dalam Rangka Penegakan Hukum.” Jurnal Prodi Strategi Pertahanan Laut Vol. 3, No. 3, 2017.

Jones, Reece, and Corey Johnson. "Border Militarisation and the ReArticulation of Sovereignty." Transactions of the Institute of British Geographers No. 41, No. 2, 2016.

Kusumaatmadja, Mochtar. Pengantar Hukum Internasional. Bandung: Alumni, 2003.

Mahmudah, Nunung. Illegal Fishing. Jakarta: Sinar Grafika, 2015. 
Sampurna, Ricky Hertian. 'Pencegahan 'Illegal Entry' Di Tempat Pemeriksaan Imigrasi Soekarno-Hatta.” Politeknik Imigrasi, 2019.

Soekanto, Soerjono. Faktor-Faktor Yang Mempengaruhi Penegakan Hukum. Jakarta: Raja Grafindo, 2007.

Soekanto, Soerjono, and Sri Mamudji. Penelitian Hukum Normatif Suatu Tinjauan Singkat. Jakarta: Rajawali Press, 1990.

Sudardi. "Peranan TNI Angkatan Laut Dalam Penegakan Hukum di Wilayah Perbatasan Laut Indonesia.” Lex Librium: Jurnal Ilmu Hukum Vol. 1, No. $1,2014$.

Suharyo. Dinamika Peranan TNI Dalam Penegakan Hukum Dan Kedaulatan NKRI, Penerapan Keadaan Bahaya dan OMSP Di Negara Demokrasi. Yogyakarta: PT Pohon Cahaya, 2016.

Tampongangoy, Grace H. "Penegakan Hukum Di Kawasan Perbatasan Indonesia.” Lex et Societatis Vol. IV, No. 5, 2016.

Wasrizal. "Penegakan Hukum Terhadap Pencurian Ikan (Illegal Fishing) Di Wilayah Perbatasan Provinsi Kepulauan Riau.” Journal of Law and Policy Transformation Vol. 5, No. 1, 2020.

Republik Indonesia. Undang-Undang Nomor 34 Tahun 2004 tentang Tentara Nasional Indonesia. Lembaran Negara Tahun 2004 No. 127. Tambahan Lembaran Negara Nomor 4439.

Purwono, Ahmad Heri. Wawancara Dengan Laksamana Pertama TNI Ahmadi Heri Purwono (Komandan Pangkalan Utama TNI AL VIII) Sulawesi Utara (Hilmi Ardani Nasution, Pewawancara), 2016.

CNBC Indonesia. "Susi Akui RI Pernah Rugi Rp 2.000 T Akibat Illegal Fishing." (Cnbcindonesia.com: https://www.cnbcindonesia.com/news/20 180626075822-4-20458/susi-akui-ri-pernah-rugi-rp-2000-t-akibat-illegalfishing), diakses 2020.

Rahman, M Razi. "Ini Nilai Kerugian Akibat Penangkapan Ikan Ilegal." (Antaranews.com: https://www.antaranews.com/berita/948003/ini-nilai-ke rugian-akibat-penangkapan-ikan-ilegal), diakses 2020. 